\title{
MEDIA COVERAGE OF 2019 SPECIAL OLYMPICS \\ WORLD GAMES IN BULGARIA
}

\author{
Stefka Djobova \\ National Sports Academy "Vassil Levski", Sofia, Bulgaria
}

\begin{abstract}
Introduction: In March 2019 Abu Dhabi hosted the Special Olympics (SO) World Games. This is the world's largest humanitarian sporting event and a global movement which focuses on the empowerment of People of Determination with intellectual disabilities through the power of sport. Bulgarian team also took part in the Games. The event realized remarkable worldwide broadcasting and media coverage. The aim of this study was to explore the extend of the media coverage at national level.

Methodology: The data concerning SO's media coverage was acquired from papers and research studies as well as from press, training, and conference materials. Specially created online focus group was established to collect personal experiences with media coverage of SO Games.

Results and discussion: The results of the study showed that there is a luck of research related media coverage of SO competitions. The 2019 SO World games were the most broadcasted and written Medias covered games ever. The same was through for the Bulgarian SO team with the biggest media coverage since the program renewal at 2003. We evaluate the national media coverage as a great success.

Conclusions: The low rate or luck of media coverage was international tendency in the last decades. There is a growing interest on behalf of the medias and particularly of the sport channels to broadcast Special Olympics World Games.
\end{abstract}

Key words: Special Olympics World Games, medias, publicity.

\section{INTRODUCTION}

Special Olympics (SO) is a global movement that provides year-round sports training along with athletic competition opportunities in a variety of Olympic-type sports for children and adults with intellectual disabilities. $\mathrm{SO}$ is giving his athletes continuing possibilities to develop physical fitness, demonstrate courage, experience joy, and participate in the sharing of gifts, skills, and friendship with their families, other Special Olympics athletes and the community. Through programming in sports, health, education, and community building, Special Olympics is changing the lives of people with intellectual disabilities, helping them to overcome the global discrimination, injustice, isolation, intolerance, and inactivity they often face. Since 1964 the Special Olympics movement has grown to more than six million athletes and Unified Partners in 174 countries. With the support of more than one million coaches and volunteers, Special Olympics holds more than 103000 competitions throughout the year.

In the Year of Tolerance from 14 to 21 of March 2019 Abu Dhabi, United Arab Emirates hosted the Special Olympics World Games for the first time in the Middle East since the movement's found- ing over 50 years ago. The Crown Prince Court led the winning bid efforts with a mission to promote positive social change for people with intellectual disabilities and create a more inclusive society. The leading theme of this year event was the "People of Determination". This way the Special Olympics became the world's largest humanitarian sporting event and a global movement which focuses on the empowerment of People of Determination with intellectual disabilities through the power of sport. The event was led under the Patronage of His Highness Sheikh Mohammed bin Zayed Al Nahyan, whose leadership and vision have been instrumental in bringing together public and private sector partners to be a part of this worthy cause. More than 7000 athletes from more than 190 countries competed in 24 summer sports, along with 2,500 coaches, 20,000 volunteers, 3,000 honored guests, and 500,000 spectators making this the largest international sporting event of the year.

Special Olympics Bulgaria was represented by its national delegation consisting of seven teams in the different sports with 18 athletes' ages 14-42 and 11 parsons - head of delegation, assistant head of delegation, coaches and medical doctor. The athletes were representatives of 10 Bulgarian municipalities. 
The Organizing Committee placed tremendous efforts for the World Games to be marketed to a national, regional, and global audience with a comprehensive campaign featuring an aggressive media relations, social media, and content marketing effort, supported by a large network of partners in all forms of media, including TV, social media, radio, publications, and more. Melvin (2019) claimed that this event will have more live coverage of such competition than ever before.

The aim of this study was to explore the extend of the media coverage of 2019 Special Olympics World Games at national level.

It is accepted that the media is an important element of cultural environment and play a key role in sport's ascendancy as a social and economic institution (Zion, Spaaij, \& Nicholson, 2011). At the same time, we randomly find positive images of athletes with intellectual disabilities. In his research Jones (2017) found that people in China complained that they had competing athletes in SO but there was no coverage. He finds that was true also of Idaho where there was no coverage of SO Games or little some.

Haller (2010) believes that it is a journalist's duty to showcase the performance because it is at the heart of their work as information architects. Tanner, Haswell, \& Lake (2003) are showing that the achievements of athletes with disabilities, particularly those with intellectual disabilities, have not yet qualified for 'real' sport status. Later the Tanner, Green \& Burns (2011) explored how the print media covered the Adelaide National SO Games focusing on a number of issues surrounding media coverage of sport for people with disabilities including the language and description of sporting excellence. In terms of coverage Myśliwiec \& Damentko (2015) recommend the exploration of progress, referring to the sporting aspect. In general, the issue of media coverage of SO athletes is not extensively researched. This is confirmed by our online survey of the Special Olympics Research Bibliography where we found only two titles responding to our key words - one report and research article (Special Olympics, 2005; and Tanner, Green \& Burns, 2011).

\section{METHODOLOGY}

The data concerning SO's media coverage was acquired from papers and research studies as well as from press, training, and conference materials. Big source of data were all guides distributed to the national delegations in the preparation process of the Games, during and after the games. The official websites of the Special Olympics, both worldwide and the national, were significant sources of information with significant contribution of the 2019 Special Olympics World Games and their mobile application. Online survey using three combinations of key words was performed. We researched additionally with key word "media" the online Special Olympics Research Bibliography 2018 edition. Specially created online focus group was established using the online conference software GoToWebinar. The focus group consisted of persons who were directly involved in 2019 SO World Games including the national team, the international teams' representatives, three persons form the Abu Dhabi organizing committee, three television reporters who were involved at minimum two World games and from seven parents of $\mathrm{SO}$ athletes. The focus group was created to bridge the gap of missing written data regarding media coverage we aimed.

\section{RESULTS AND DISCUSSION}

To showcase the extend of the international media coverage we identified the media stakeholders. The main broadcast partners of the Special Olympics World Games 2019 were Abu Dhabi Media and ESPN. Abu Dhabi Media (ADM) is one of the fastest growing, multi-platform media and entertainment organizations in the Middle East. ESPN (originally an initialism for Entertainment and Sports Programming Network) is a U.S.-based pay television sports channel owned by ESPN Inc., which is available to approximately 86 million television households. The media partners were MBC Group, Pro League Committee, Sky News Arabia and The National with media supplier Haykal Media. The Middle East Broadcasting Center branded as MBC is the largest private free-to-air satellite broadcasting company in the Middle East \& North Africa region. The Pro League Committee, commonly known as PLC, is sports association and the organizing body of football leagues of the United Arab Emirates. Sky News Arabia is an Arabic 24hour rolling news channel broadcast mainly in the Middle East and North Africa. The National is publishing across all digital platforms with more than 10 million pageviews per month. The National binds the latest multimedia tools while continuing to produce a print edition six days a week. The 
official media sponsors were Al-Roeya and World Wrestling Entertainment. All major social media networks as Facebook, Twitter, Instagram, LinkedIn and YouTube were also involved. We may conclude that on international level real media tycoons were directly involved.

ESPN's global television networks and digital media brought extensive coverage to sports fans and supporters of the Special Olympics movement around the world. As the official broadcast partner of Special Olympics, ESPN's coverage was carried across its ESPN/ABC networks in the U.S. as well as streamed through WatchESPN and the ESPN App. The media coverage of ESPN is presented on Table 1.

Table 1. ESPN Broadcasting

\begin{tabular}{|l|l|}
\hline \multicolumn{2}{|c|}{ ESPN's broadcast coverage } \\
\hline $\mathbf{3}$ hours & Opening Ceremony. \\
\hline Daily live feeds & Delivered more than 25 hours of live coverage across venues and competitions. \\
\hline Daily evening studio & $\begin{array}{l}\text { Programs brought viewers the incredible stories, athlete profiles and features, as well } \\
\text { as recapping key results from each days' competitions. }\end{array}$ \\
\hline $\mathbf{2}$ hours & $\begin{array}{l}\text { 'Best of" special aired on ABC - two-hour program highlighting the amazing } \\
\text { competitions and the spectacular closing ceremonies. }\end{array}$ \\
\hline $\begin{array}{l}\mathbf{7} \text { articles } \\
\mathbf{1 7} \text { videos }\end{array}$ & 24 titles of features, news and video available on the website. https://www.espn.com \\
\hline
\end{tabular}

The six years media partnership between ESPN and Special Olympics contributed to the following: Increased Unified Sports athlete and teammate participation by $172 \%$ since 2013 , to nearly $1,815,000$ as of 2019; Increased the number of Unified Sports coaches by $464 \%$, to nearly 119,000 coaches; Increased overall global sponsorship revenue associated with Unified Sports by $300 \%$ in six years. In addition to the remarkable broadcasting ESPN and Special Olympics Expand Relationship with Eightyear Broadcast Agreement and Extension as Global Presenting Sponsor of Special Olympics Unified Sports (Couch, 2019).

In Bulgaria the preparation of the team and the first media coverage events started with the launch of the \#BEUNIFIED campaign. As a result the Bulgarian SO athletes returned from the Games with 19 medals, 16 fourth places, two 5th and 6th, 7th and 8th places won by the athletes of Special Olympics Bulgaria in 7 sports - track and field, bocce, badminton, horse riding, swimming, power lifting and tennis. According the Special Olympics Bulgaria (2019) we reached significance in the involvement of the athletes in a number of public events such as interviews in the national radio, five TV Chanel, press conferences, opening and closing ceremonies of sport or cultural events. The \#BEUNIFIED campaign managed to raise awareness and interest towards the athletes. Majors and the Minister of Youth and Sport in Bulgaria showed personally their respect to the athletes and all this was broadcasted in a short news reports at the national and local TV channels. Following the trace of increased interest, a FAN.bg page was developed to allow performance information for each athlete. Seven hundred promo videos were shown at the screens on metro stations and 4760000 travelers have seen them. Huge billboards were promoting the Games on the highways. Twenty-one original video cards and promotional videos on the official Facebook page of Special Olympics Bulgaria were placed with 12,355 views of the advertising videos. 109130 Facebook users have seen the content of the \#BEUNIFIED campaign, and we received 257 169 unique Facebook campaign views. 745 fails were downloaded from the virtual press room. The team received 2500 white cards and 40 publications for support during the International day of sport for development and peace. 132 medias covered the Bulgarian SO Team as follows: Institutions- 14; National and Regional Televisions - 8; Radia- 9; Agencies- 6; Newspapers- 3; Media Online- 73; International Media- 15; Outdoor Advertising4. During the games 20 videos were broadcasted. Eight TV channels and nine radio channels reported about the Games. For a firs time 15 international TV channels showed reports for the participation of SO Bulgaria. This could be explained with the public sensitivity towards inclusion and the professionalism of the national SO director and his team. Furthermore, contribution to this result should be credited the Media Coordinator Diana Bancheva. 
Although limited number of research covering the media coverage of Special Olympics is available and having in mind the results shown Tanner, Haswell, \& Lake, (2003) stating that the achievements of athletes with disabilities, particularly those with intellectual disabilities, have not yet qualified for 'real' sport status we might argue that situation at 2019 has changed. We might conclude that the situation after 2010 has changed and the media coverage of the 2019 SO World Games tremendously increased worldwide. The journalists are focusing on the performance and the sporting excellence of the athletes. Contribution to the awareness has been brought also by the Social Medias and is highly recommendable to research in depth their involvement and to explore them as tools for attitude change and awareness raiser. As Tanner, Haswell, \& Lake, (2003) suggest in order to understand media coverage of disabled sport, it is important to appreciate how journalists and other people in the news chain make decisions regarding the suitability of stories. Seems that event such as the SO World games is attractive and sells the most live stories of SO athletes together with their sport abilities. The location of 2019 SO World games and the fact that it was heled there for a first time was also an attraction to the Medias. The same tendency we found in Bulgaria where for the first time ever we have such a large-scale media coverage.

\section{CONCLUSION}

In this study, it became clear that where is a lack of research on media coverage of Special Olympic athletes in general and of the World games as a culmination event in particular. Following the global initiative for inclusion in sport news channels are more open to broadcast events where athletes of Special Olympics participate. Bulgarian team who participated in the 2019 SO World Games appeared in significant number of media means which is highly satisfactory for the athletes, the parents of the athletes and board of Special Olympics Bulgaria.

\section{REFERENCES}

Couch, T. (2019). ESPN and Special Olympics Expand Relationship with Eight-year Broadcast Agreement and Extension as Global Presenting Sponsor of Special Olympics Unified Sports. ESPN pressroom, 20 Sept.

Haller, T. (2010). Attending to performance. Bulletin of the American Society for Information Science and Technology. Volume 36, Issue 3, pp. 55-56.

Jones, J. (2017). Coverage of Special Olympics - Where Were the Major Television Networks. Disabled World, Electronic Journal. Available at: https://www.disabled-world.com/sports/special-olympics/special-olympics-tv.php - Reference Category Number: DW\#2021217. (accessed 20 July 2019)

Melvin, P. (2019). ESPN's Coverage of Special Olympics World Games Abu Dhabi 2019 Kicks Off in One Month. ESPN pressroom, 15 February.

Myśliwiec, A., Damentko, M. (2015). Global initiative of the Special Olympics movement for people with intellectual disabilities. Journal of human kinetics, 45, pp. 253-259.

Special Olympics (2005). Changing Attitudes Changing the World: Media's Portrayal of People with Intellectual Disabilities. Washington, DC: Special Olympics, Inc.

Special Olympics (2018). Special Olympics Research Bibliography. Edition 2018. available at: https://dotorg.brightspotcdn.com/f0/14/f2dbf004425ba94270a29fae42b0/2018-special-olympics-research-bibliography-april.pdf. (accessed 3 July 2019)

Special Olympics Balgaria (2019). Otchet nacionalna kampania "Da badem zaedno!" za uchastie v svetovnite letni igri na Spacial Olympics v Abu Dhabi'2019. Sofia // Спешъл Олимпикс България (2019). Отчет национална кампания „Да бъдем заедно!“ за участие в световните летни игри на спешъл олимпикс в Абу Даби'2019. София.

Tanner, S., Haswell, S., Lake, M. (2003) Promoting the ideals of integration and diversity. Media coverage of Special Olympics Australia. Australian Journal of Communication, 30.3, pp. 123-141.

Tanner, S., Green, K., Burns, S. (2011). Media Coverage of Sport for Athletes with Intellectual Disabilities: The 2010 Special Olympics National Games Examined. Media International Australia, 140(1), pp. 107-116.

Zion, L., Spaaij, R., Nicholson, M. (2011). Sport Media and Journalism: An Introduction. Media International Australia, 140(1), pp. 80-83.

\section{Corresponding author:} Stefka Djobova, PhD National Sports Academy "Vassil Levski" 21 Acad. Stefan Mladenov, str. Sofia, 1000, Bulgaria E-mail: stefka.djobova@abv.bg 